\title{
Employment Difficulties and Coping Strategies of College English-majored Graduates
}

\author{
Xiaoyi LIU \\ Foreign Language Department of Jilin Business and Technology College \\ Changchun City, China, \\ Email:lihongbin1975@163.com
}

\begin{abstract}
The employment difficulty of English-majored graduates in colleges and universities is an indisputable fact, the main reasons for which consist of blind enrollment and expansion of colleges, immaturity of college English construction, the dated college English teaching mode and the imparity of job-choosing view. To change this situation, universities must set up corresponding theories on school management to the students' employment, improve their own talent training programs and optimize the curriculum, so, a professional practice platform and a high-quality teachers team can be built up for students.
\end{abstract}

Keywords—college English majors; graduates;
countermeasures

Since China's accession to the WTO, globalization process is further accelerated and international communication is becoming more and more frequent. With this process, English become the first choice of communication languages around the world, thus there is an increasing demand for English talents. A few years ago, there was an idea formed in society: With a good knowledge of English, no worry about being employed. Influenced by this concept, English becomes a hot major of a high popularity and becomes the first choice of multitudinous high school students when filling volunteer of universities. This objectively causes an overheating and prosperous phenomenon. However, people ignore the gap in market's demand of English talents and the actual output of talents, which eventually leads to a cold welcome that Englishmajored graduates are faced with in employment. Due to the relatively simple knowledge structure of English major students, the difficulty in employment is an indisputable fact. In such a tough market, how to rationally treat the difficulty in employment and solve the problem has become a top topic that the universities and society needs to face seriously.

\section{CURRENT EMPLOYMENT SitUATION ANALYSIS OF COLLEGE ENGLISH-MAJORED GRADUATES}

\section{A. "Blue chip" to "Dark horse"}

According to the ministry of human resources and social security, from 2000 to 2009, the employment rate of college English major graduates has been ranked among the top 10. Especially along with China's accession to the WTO and the successful hosting of the Olympic Games in Beijing, English major graduates employment prospects constantly look to further improvement. However, since 2010, the employment rate of college English major graduates has been being ranked at the top of the charts. Due to the unemployment rate, English major has been designated as a low-employed and high-risk major with poor salary. This means that the prospects of English majors in colleges have showing a trend from "Blue chip" to "Dark horse", receiving little attention from society.

\section{B. "Low-threshold" to "High-threshold"}

According to related survey, what the current job market needs are high-end talents with proficient and professional skills and high adaptability to social needs. For instance, simultaneous interpretation requires practitioners to have strong English listening and speaking skills and high sense of both English and Chinese languages. In addition, practitioners must not only thoroughly understand knowledge of politics, finance, manufacture, environmental protection, culture, ${ }^{[1]}$ philosophy and so on, but also react quickly and think promptly. Therefore, this area has been listed as the most talented person and the highest value field. Thus, the threshold for English majors has been changing from "low-threshold" to "high-threshold".

\section{C. "Specialized" to "All-round"}

English is a communication tool, so the English-majored students not only should have corresponding professional and theoretical knowledge, but also have a wide knowledge of other fields when communicating with people in English. For example, graduates majored in business English should have the theoretical knowledge and strong pragmatic competence, be familiar with business law and regulations, master computer and modern office equipments operation skills, and understand policies, regulations and industry practices in foreign trade, international business, accounting, finance, investment, insurance, tourism and other industries. This means that graduates in such major should have the ability to combine theory with practice and make themselves become a inter-disciplinary talent can meet the need of the market. 


\section{ANALYSIS OF FACTORS INFLUENCING COLLEGE ENGLISH- MAJORED GRADUATES' EMPLOYMENT}

\section{A. Full demand for English-majored talents due to blind expansion and enrollment}

A few years ago, in the tide of enrollment and expansion of colleges and universities, the most major expanded is English. Relevant investigation shows that in the late 1990s, colleges with qualification of English bachelor's degree in China are more than 200, which are up to 598 by 2004 and 959 by 2011. English major meanwhile, is also expanding from comprehensive and normal specialties to finance, engineering, agriculture and forestry and literature, which leads to the full demand for English-majored talents. ${ }^{[2]}$

\section{B. English major construction divorced from market demand}

In recent years, some emerging fields become immortal place for the employment of English-majored graduates, such as media, financial, telecommunications, consulting, logistics, entertainment, sports industry, etc. These industries have a high requirement for the applicability of English, capacity and overall quality of English-majored graduates. But at present, some colleges and universities have an immature construction of English major because the objectives of most English majors in colleges and universities are still mainly concentrated on the construction of English linguistics, British and American culture, English learning and education, but talents majored in translation, cultural studies, business English, English of science and technology, corpus linguistics and other majors cannot satisfy the needs of the market.

\section{Non-scientific teaching mode and deficiency in comprehensive ability}

At present, the teaching mode of college English majors cannot well adapt to the requirement of English-majored graduates employment. For many colleges and universities, their teaching content is limited to textbook, which eventually leads to students' dated knowledge and unreasonable structure. At the same time, teachers are often self-centered in the teaching process and adopt forcefeeding teaching mode, which totally ignores students' learning enthusiasm and initiative and neglect students' autonomous learning ability and practice ability. In this way, after four years' study in university, students are still far away from professional knowledge, strong applicability and high competitive ability.

\section{Immature job-choosing view}

After entering the university, many students lose their learning motivation and have an unclear career development goal. Many students never think seriously about their prospects, let alone a specific career planning, which is caused by students' lack of awareness of the fierce employment and competition after graduation and therefore lack of initiative for the smooth realization of employment. At graduation, many students only consider the immediate interests, regardless of their own expertise and long-term development needs. Without a correct view of job-choosing, they tend to lose some reasonable employment opportunities. What's worse, because of excessive consideration of treatment, they focus more on regional issues and become voluntarily jobless.

\section{COPING MEASURES TO PROMOTE THE EMPLOYMENT OF COLLEGE ENGLISH-MAJORED GRADUATES}

\section{A. Setting up corresponding teaching concept to employment and improving the comprehensive quality of English-majored talents}

The employability of college graduates refers to the ability of college students to obtain employment and maintain employment after graduation, which is a combination of knowledge, ability and attitude of university graduates to appeal to the employers. With the intensification of employment competition, it has attracted widespread attention to explore how English major teaching adapts itself to the needs of society, which has also become a major issue that college English major education must face. Therefore, colleges and universities should attach great importance to this problem and reform their education teaching modes. In order to implement the reform at present, it is important that English education should conform to the needs and development of society, economy, science and technology.

\section{B. Improving talents cultivation scheme, optimizing curriculum system and cultivating graduates' employability}

To improve the quality of college English-majored talents, colleges must according to the requirements for English professional talents' knowledge, ability and quality, further define the talents cultivation scheme. In the construction of curriculum system, it is necessary to consider the characteristics of English majors, design a reasonable course structure, clear position and function of all kinds of the courses, and reasonably arrange the relationship of basic theory, required courses, elective courses and other related professional courses, so as to make it consistent with the requirements of teaching objectives and put teaching reform into effect.

\section{Optimizing curriculum and emphasizing practice}

Traditional teaching pays attention to the knowledge in textbook but ignores the cultivation of students' practical ability, resulting in the disjunction between theory and practice, knowledge and ability, professional learning and culture learning, which further leads to students' deficiency in listening and speaking skills, ${ }^{[3]}$ cultural quality and overall quality. A survey in Jiangsu Province has found that 91\% enterprises believe graduate must have an English applicability in various fields. In order to cultivate the students' employability, colleges must improve their own professional curriculum optimization and enable students to participate in the activities of English practice. Students will inevitably encounter their unpredictable practical problems 
in the process of practice, which require students to solve through self-study or reference to the experience of others.

\section{Constructing platform for major practice}

At present, there is an obvious gap between theoretical and practical courses. To solve this problem, the implementation of practical teaching is a must. So, it is necessary to strengthen the construction of practice teaching, provide more direct experience as much as possible for students and promote the formation of students' career ability in the premise of clear professional directivity. Today, practice teaching is varied to meet the needs of the students' employment, but the most important thing is to strengthen all kinds of comprehensive practice drills, such as spoken ability of English speech and debate, writing ability of academic paper, professional translation ability, expressive ability of Chinese and western culture and penetration ability under the multidisciplinary background. It is helpful for students to show their talent and form innovation ability. At the same time, colleges and universities may also depend on society and enterprises and arrange students to social relevant departments for comprehensive practice exercises. It is beneficial for students to practice the activities with "gold content", enhance specific goal of practice and fully exercise their ability to use English. ${ }^{[4]}$

\section{E. Constructing qualified teaching faculties}

Colleges and universities should strengthen the examination and evaluation of teachers' performance in theoretical practice. College teaching teams should follow up teachers' teaching process and hold teaching analysis meeting regularly, so that they can listen to students' feedback and timely put forward solutions to the problems. Colleges should also establish a link between teachers' quality and teachers' evaluation awards. Part of the teachers' teaching content is very rich and teaching attitude is also very serious, but the lack of employment content will divorce theory from practice. Therefore, teachers should try to increase their understanding of society and enterprise.
Apart from regular visit and survey, teachers should also be more involved in social practice, keep in contact with the people engaged in English related work and learn about their working condition and demand. With the rich practical experience, it helps to improve the classroom teaching.

\section{CONCLUSION}

University students' employment is forever a new topic. College students, especially college students majored in English, are affected by the global financial crisis, whose employment suffers from a great impact, so they should view from international perspective, fostering a correct concept of career, employment and constantly improving their professional quality and comprehensive ability. Colleges are supposed to provide employment guidance and psychological consultation so as to construct a platform for English-majored students' employment. Government needs to build system and policy related to employment, guiding enterprises to recruit fairly and encourage students to get involved to the grassroots employment and self-employment. Only in this way can the difficulty in employment of the English-majored graduates be gradually improved, so as to ensure their employment to be fair and smooth employment and promote the harmonious development of society as a whole.

\section{REFERENCE}

[1] Yang Zhijian. Causes and countermeasures of the difficulty in college graduates' employment.[J] Journal of Ningxia University: Humanities and Social Sciences,2011,33(4).

[2] Gao Fengping, Liu Xinsen. Causes and measures of college Englishmajored graduates' dilemma in employment.[J]. Journal of Weinan Teachers College,2011(4):21

[3] Wu Qi. Dynamic evaluation of English writing teachingTeacher's intervation exploration[J]. English Teacher, 2013, 05:23-28

[4] Sun Sainan. The influence of dynamic assessment in college English writing teaching [J].Journal of Kaifeng Institute of Education ,2014,08:135-136 